\title{
Erratum zu: Weiterbildungsbeteiligung - Ursachen unterschiedlicher Teilnahmequoten in verschiedenen Datenquellen
}

\author{
Merlind Eisermann · Florian Janik • Thomas Kruppe
}

Online publiziert: 06. November 2014

(C) Springer Fachmedien Wiesbaden 2014

\section{Erratum zu: Z Erziehungswiss (2014) 17:473-495 DOI: 10.1007/s11618-014-0561-y}

Durch ein technisches Versehen ist der folgende Hinweis im Beitrag „Weiterbildungsbeteiligung - Ursachen unterschiedlicher Teilnahmequoten in verschiedenen Datenquellen (Participation in adult education: the reasons for inconsistent participation rates in different sources of data)" nicht abgedruckt worden:

Die Ergebnisse des Artikels stammen aus dem Projekt „Weiterbildungsbeteiligung in Deutschland“, welches vom Bundesministerium für Bildung und Forschung finanziert wird.

Due to a technical accident, the following information is missing in the article „Weiterbildungsbeteiligung - Ursachen unterschiedlicher Teilnahmequoten in verschiedenen Datenquellen (Participation in adult education: the reasons for inconsistent participation rates in different sources of data)“:

The results of the article stem from the research project ,Weiterbildungsbeteiligung in Deutschland" which is financed by the Federal Ministry of Education and Research.

Die Onlineversion des Originalbeitrages ist erreichbar unter doi: http://dx.doi.org/10.1007/s11618-014-0561-y

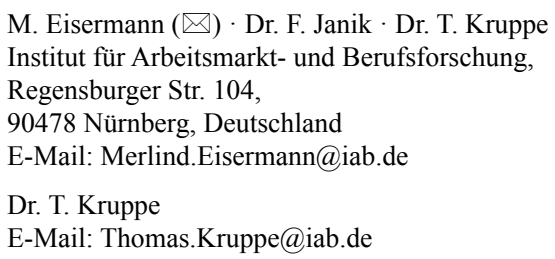

